\title{
Development of Emission to Air in Central Europe
}

\author{
Jozefína Pokrývkováa*, Luuboš Jurík \\ 1 Department of Landscape Engineering, Horticulture and Landscape Engineering Faculty, Slovak University \\ of Agriculture in Nitra, Hospodárska 7, Nitra 949 76, Slovakia \\ * Corresponding author's e-mail: jozefina.pokryvkova@uniag.sk
}

\begin{abstract}
The present state of air quality is determined according to emission and imission situation of basic pollutants. According to the obtained information about the state of air quality, the development of imission and emission presently exhibits a decreasing tendency caused especially by industrial production innovations in European countries, with slight rises in renewable energy sources for electricity production, but especially the effort to improve the condition relates to the use of mandatory quotas and pollution charges in the European Union. The aim of the this article is to review the emission development in the year 1998 up to 2013 for Central European countries - Slovakia, Czech Republic and Poland and their comparison to the European average value of the released emission. The NOx and particulate matter $\mathrm{PM}_{10}, \mathrm{PM}_{2,5}$ were evaluated as pollutants, which over the last few years have contaminated the air and in particular the main environment.
\end{abstract}

Keywords: air quality, emissions $\mathrm{NO}_{\mathrm{x}}, \mathrm{PM}_{10}, \mathrm{PM}_{2,5}$, air imission, pollution modelling

\section{INTRODUCTION}

Rarely do people think that they are part of nature and cannot survive without it. We still live under the impression that that landscape is large enough that the negative impact exerted by us is not visible. Nevertheless, the human intervention into nature through technology and the progress of industrialization cause changes in nature, sometimes with unforeseeable consequences. [Homer-Dixon, 1999]. All branches of industry produce excessive amounts of emissions, wastes, causing water pollution and soil pollution.

The atmosphere is an especially sensitive component of the environment that is affected especially by the human needs to raise their living standards. With the rapid growth of production and consumption, exploitation of renewable or non-renewable natural resources on the one hand, a number of different types of wastes, often unacceptable for the nature, are discharged into the environment on the other. The formed pressure of modern society develops the changes especially in the air [Monteiro, 2017]. Air quality represents one of the marks for measurement of the environmental quality and its state. The present state of the air quality is determined through emission and imission situation of basic pollution materials [Lenárt et al. 2012]. On the basis of the obtained information about the air state and quality, the development of imission and emission, currently exhibits a decreasing tendency caused especially by innovation of the industrial production in Europe, by moderate increase of renewable source utilization as the energy source The improving state is caused by implementation of obligatory quotas and pollution fees in the frame of the European Union [Holland, 2006].

Air pollution can be modelled by various kinds of software; the most efficient is GIS modelling [Leitmanová et al. 2013]. The general trend of PM air pollutant concentrations in the air in European Union is decreasing, but it is important to continue its monitoring and observation. Particulate matter (PM) pollution is presently one of the main concerns worldwide, for its adverse effects on the human healthiness, climate and environment [Gozzil, 2017]. 


\section{MATERIAL AND METHODS}

Since 1950, the regional air pollution in Europe has increased in parallel with the pollution emitted by energy, industry, transport and heating. The construction of high chimneys prolonged the residence time of air pollutants in the air. In this large region that is strongly influenced by the developed industry, primarily sulphur and nitrogen are major problems, in addition to the resulting acid rain and acidification of the whole environment. The consequence of the uncontrolled emission development was the increase of acidity of precipitation. The acid precipitation and ozone are currently the main stress factors of the forest and field ecosystems in Europe [Flash Eurobarometer 360, 2013].

The basic air pollutants are mainly NOx and fine and dust particles PM, produced from all types of combustion, incineration and some industrial processes.

NOx are emitted during incineration of a fuel, for example at the industrial installations and in the road transport sector. This group of gases contains nitric oxide (NO) and nitrogen dioxide $\left(\mathrm{NO}_{2}\right)$. The concentrations of the nitrogen oxides in free air underlie the changes depending on sunshine intensity in UV area and air mass movement.

PM is a mixture of aerosol elements (solid and liquid), which are in wide scale of sizes and are characterized by different chemical composition. Flying dust presents the sum of elements with different size, which are freely dispersed in the air. They originate from different technological processes; they are released especially during burning of solid materials contained in the exhaust gases of motor vehicles. They infiltrate into the air also by whirling the elements fixed on the earth surface (secondary dustiness). The $\mathrm{PM}_{10}$ are $50 \%$ of elements with aerodynamics parameter lower than $10 \mu \mathrm{m}$. The elements with the given size can be emitted from natural sources (volcanic activity, dust storms) as well as from anthropogenic ones (power stations, industrial processes, traffic, home fireplaces, combustion stations of communal and industrial wastes).

Next, we compared Slovakia, Czech Republic and Poland in connection to the measured emissions and imission situation in Europe.

Slovakia is situated in the centre of Europe in the area with the largest regional air pollution of the continent. The share of the transboundary remote transfer of air pollutants on regional air pollution and acidity of rainfall waters of Slovakia is approximately $60 \%$. Unfavourable development, together with alarming growth of ecological damages, necessitated the international cooperation.

Czech Republic is situated in the hearth of Europe. It was founded in the year 1993 after disintegration of Czechoslovakia into two separate countries. In the 1990s, the Czech Republic invested a lot of finances for emission reduction (especially from big power stations), whereby the air quality was improved, especially in the regions which were characterized by the worst situation in the world. Industrial and traffic development after the year 2000 caused deterioration of the air quality in Slovakia. The human activity also contributes to deterioration of the situation especially by heating in home with poor-quality fuel or communal waste that releases dangerous materials into the air. Currently, the most significant problem is represented by soft dust. The Ministry of the Environment in the year 2007 elaborated the National programme of emission reduction in Czech Republic, which was consequently authorized by the Government. This document contains some key measures for improving the present state of environment and human health [Hemerka, 2010].

Poland is the country in the middle Europe bordering with Germany (west), Czech Republic and Slovakia (south), Ukraine and Belarus (east) and Lithuania and Russian exclave Kaligin area (north). Poland has a long coast of Baltic Sea. On the south, the Carpathian Mountains divide the catchments and create the natural boundary with Slovakia [Nowicki, 1993].

Between Poland and Czech Republic, the Information Air Quality System was built in the area of Polish-Czech borderland in Silesia and Moravian -Silesia region. The need for this system results from long-term unsatisfactory air quality in the Czech and Polish regions. Short-term and long-term limits of pollutants in the air, especially suspended elements (dusty aerosol), are exceeded here. It is increasing the interest of citizens on the state and reason of the air pollution; discussions are organized and speculations appear about the influence of cross-border transfer of these pollutants from Poland to Czech Republic and backward [Nowicki, 1993].

Limit values were established according to the Direction of European Parliament and Council 2008/50/ES from $21^{\text {st }}$ May 2008 about the quality of the air and cleaner air in Europe and Ambient (outdoor) air quality and health (the Health World Organization) in table 1. 
Table 1. Determination of requirements for assessment of concentrations of nitrogen dioxide and oxides of nitrogen, particulate matter $-\mathrm{PM}_{10}$ and $\mathrm{PM}_{2,5}$ [Directive 2008/50/EC and WHO]

\begin{tabular}{|c|c|c|c|c|c|}
\hline \multirow{2}{*}{\begin{tabular}{l}
\multicolumn{1}{c}{ Specification } \\
Nitrogen dioxide \\
and oxides of \\
nitrogen
\end{tabular}} & \multicolumn{3}{|c|}{$\begin{array}{l}\text { Directive 2008/50/EC of the European Parliament and of the Council } \\
\text { of } 21 \text { May } 2008 \text { on ambient air quality and cleaner air for Europe }\end{array}$} & \multicolumn{2}{|c|}{$\begin{array}{l}\text { WHO Ambient (outdoor) air } \\
\text { quality and health }\end{array}$} \\
\hline & $\begin{array}{l}\text { Hourly limit value for the } \\
\text { protection of human health } \\
\left(\mathrm{NO}_{2}\right)\end{array}$ & $\begin{array}{l}\text { Annual limit value } \\
\text { for the protection of } \\
\text { human health }\left(\mathrm{NO}_{2}\right)\end{array}$ & $\begin{array}{l}\text { Annual critical level } \\
\text { for the protection of } \\
\text { vegetation and natural } \\
\text { ecosystems }\left(\mathrm{NO}_{\mathrm{x}}\right) \\
\end{array}$ & $\mathrm{NO}_{2}$ & \\
\hline $\begin{array}{l}\text { Upper } \\
\text { assessment } \\
\text { threshold }\end{array}$ & $\begin{array}{l}70 \% \text { of limit value }(140 \mu \mathrm{g} / \\
\mathrm{m}^{3}, \text { not to be exceeded more } \\
\text { than } 18 \text { times in any calendar } \\
\text { year) }\end{array}$ & $\begin{array}{l}80 \% \text { of limit value } \\
\left(32 \mu \mathrm{g} / \mathrm{m}^{3}\right)\end{array}$ & $\begin{array}{l}80 \% \text { of critical level } \\
\left(24 \mu \mathrm{g} / \mathrm{m}^{3}\right)\end{array}$ & $\begin{array}{l}40 \mu \mathrm{g} / \mathrm{m}^{3} \\
\text { annual mean }\end{array}$ & \\
\hline $\begin{array}{l}\text { Lower } \\
\text { assessment } \\
\text { threshold }\end{array}$ & $\begin{array}{l}50 \% \text { of limit value }(100 \mu \mathrm{g} / \\
\mathrm{m}^{3}, \text { not to be exceeded more } \\
\text { than } 18 \text { times in any calendar } \\
\text { year })\end{array}$ & $\begin{array}{l}65 \% \text { of limit value } \\
\left(26 \mu \mathrm{g} / \mathrm{m}^{3}\right)\end{array}$ & $\begin{array}{l}65 \% \text { of critical level } \\
\left(19.5 \mu \mathrm{g} / \mathrm{m}^{3}\right)\end{array}$ & $\begin{array}{l}200 \mu \mathrm{g} / \mathrm{m}^{3} \\
1 \text {-hour mean }\end{array}$ & \\
\hline $\begin{array}{l}\text { Particulate } \\
\text { matter }\left(\mathrm{PM}_{10} /\right. \\
\left.\mathrm{PM}_{2,5}\right)\end{array}$ & 24-hour average $\mathrm{PM}_{10}$ & Annual average $\mathrm{PM}_{10}$ & Annual average $\mathrm{PM}_{2,5}$ ) & $\mathrm{PM}_{2.5}$ & $\mathrm{PM}_{10}$ \\
\hline $\begin{array}{l}\text { Upper } \\
\text { assessment } \\
\text { threshold }\end{array}$ & $\begin{array}{l}70 \% \text { of limit value }(35 \mu \mathrm{g} / \\
\mathrm{m}^{3}, \text { not to be exceeded more } \\
\text { than } 35 \text { times in any calendar } \\
\text { year) }\end{array}$ & $\begin{array}{l}70 \% \text { of limit value } \\
\left(28 \mu \mathrm{g} / \mathrm{m}^{3}\right)\end{array}$ & $\begin{array}{l}70 \% \text { of limit value } \\
\left(17 \mu \mathrm{g} / \mathrm{m}^{3}\right)\end{array}$ & $\begin{array}{l}10 \mu \mathrm{g} / \mathrm{m}^{3} \\
\text { annual mean }\end{array}$ & $\begin{array}{l}20 \mu \mathrm{g} / \mathrm{m}^{3} \\
\text { annual mean }\end{array}$ \\
\hline $\begin{array}{l}\text { Lower } \\
\text { assessment } \\
\text { threshold }\end{array}$ & $\begin{array}{l}50 \% \text { of limit value }(25 \mu \mathrm{g} / \\
\mathrm{m}^{3} \text {, not to be exceeded more } \\
\text { than } 35 \text { times in any calendar } \\
\text { year) }\end{array}$ & $\begin{array}{l}50 \% \text { of limit value } \\
\left(20 \mu \mathrm{g} / \mathrm{m}^{3}\right)\end{array}$ & $\begin{array}{l}50 \% \text { of limit value } \\
\left(12 \mu \mathrm{g} / \mathrm{m}^{3}\right)\end{array}$ & $\begin{array}{l}25 \mu \mathrm{g} / \mathrm{m}^{3} \\
24-\text { hour } \\
\text { mean }\end{array}$ & $\begin{array}{l}50 \mu \mathrm{g} / \mathrm{m}^{3} \\
24-\text { hour } \\
\text { mean }\end{array}$ \\
\hline
\end{tabular}

\section{RESULTS AND DISCUSSION}

The results part contains the emission review from the year 1998 till 2013 for Slovakia, Czech Republic and Poland as compared to the evolution of European average emissions. Such pollutants, as $\mathrm{PM}_{10}, \mathrm{PM}_{2,5}$, which over the last years have endangered the environment and especially human environment, were evaluated. Other pollutants included $\mathrm{NO}_{\mathrm{x}}$, because in comparison with the sulphur oxide concentrations, they have been rapidly reducing, the $\mathrm{NO}_{\mathrm{x}}$ reduction is less visible due to increased gas amount as burning medium and especially in connection with $\mathrm{O}_{3}$, and road traffic (in the past there were techno- logical processes and high temperature burning with bond of air nitrogen).

The emission development of $\mathrm{PM}_{10}$ for selected the states (Fig.1) for the years 1990-2013 is reasonably decreasing, but these decreased trends also exert unfavourable influences on the environment in the interested countries.

Expert health studies show that in the localities with high or long-term occurrence of increased concentrations of small dust elements in the air, a higher number of deaths due to respiratory organ and cardio-vascular diseases is determined [Pokrývková, 2016].

Such groups of population as asthmatics, persons with respiratory organs and cardio-vascular

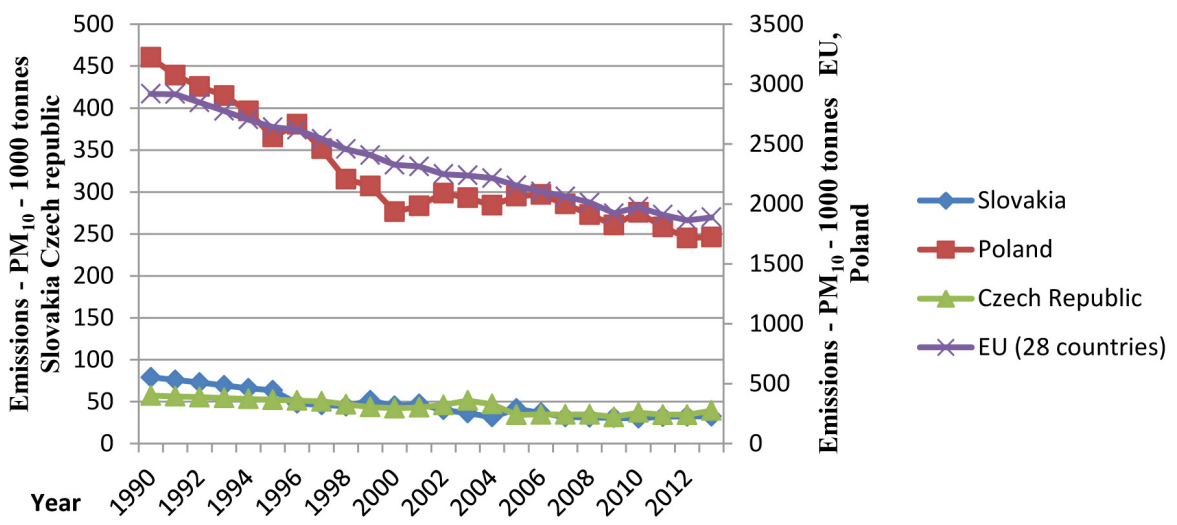

Fig. 1. Development of $\mathrm{PM}_{10}$ emission in selected countries in the years 1990-2013 
diseases, very small children and old people are especially sensitive. The influences on death, hospitalization due to respiratory and cardio-vascular diseases was monitored on the level of $100 \mu \mathrm{g} . \mathrm{m}^{-3}$ expressed as a daily average concentration $\mathrm{PM}_{10}$. Due to this reason, according to WHO limiting the value for short-term average concentration it is not recommended. The information about the long-term effects of $\mathrm{PM}_{10}$ elements is still impoverished. Some studies show the fact that the long-term exposition to $\mathrm{PM}_{10}$ elements can reduce the expected life length by about 1-2 years. Other studies indicate that the occurrence of bronchial syndromes for children and reduction of lung function of children and adults is connected with the exposure to $\mathrm{PM}_{10}$. These effects were monitored for an average annual concentration under $20 \mu \mathrm{g} \cdot \mathrm{m}^{-3}$ (as $\mathrm{PM}_{2,5}$ ) and $30 \mu \mathrm{g} \cdot \mathrm{m}^{-3}$ $\left(\mathrm{PM}_{10}\right)$. The limit value for long-term exposure to $\mathrm{PM}_{10}$ was not determined.

\section{PM EMISSION DEVELOPMENT}

The measured values of $\mathrm{PM}_{10}$ imission of in $\mu \mathrm{g} . \mathrm{m}^{-3}$ (Fig.2) for the years 1998-2013 are compared with the limit values determined by EU and WHO Direction. In the case of Poland, both limit parameters are exceeded. As for the limits of EU, it is variable for the individual years in Slovakia and Czech Republic. All countries exceed the defined values in the case of comparison of these values with the limits defined by WHO.

Emission development of $\mathrm{PM}_{2,5}$ for the considered countries (Fig.3) for the years 1990-2013 is very similar as for the $\mathrm{PM}_{10}$ emission, and it is a decreasing trend.

The $\mathrm{PM}_{2,5}$ imission values in $\mu \mathrm{g} . \mathrm{m}^{-3}$ (Fig.4) for the years 1998-2013 are compared with the limit values determined by the EU and WHO Direction. All investigated countries exceeded the limits determined by EU and WHO.

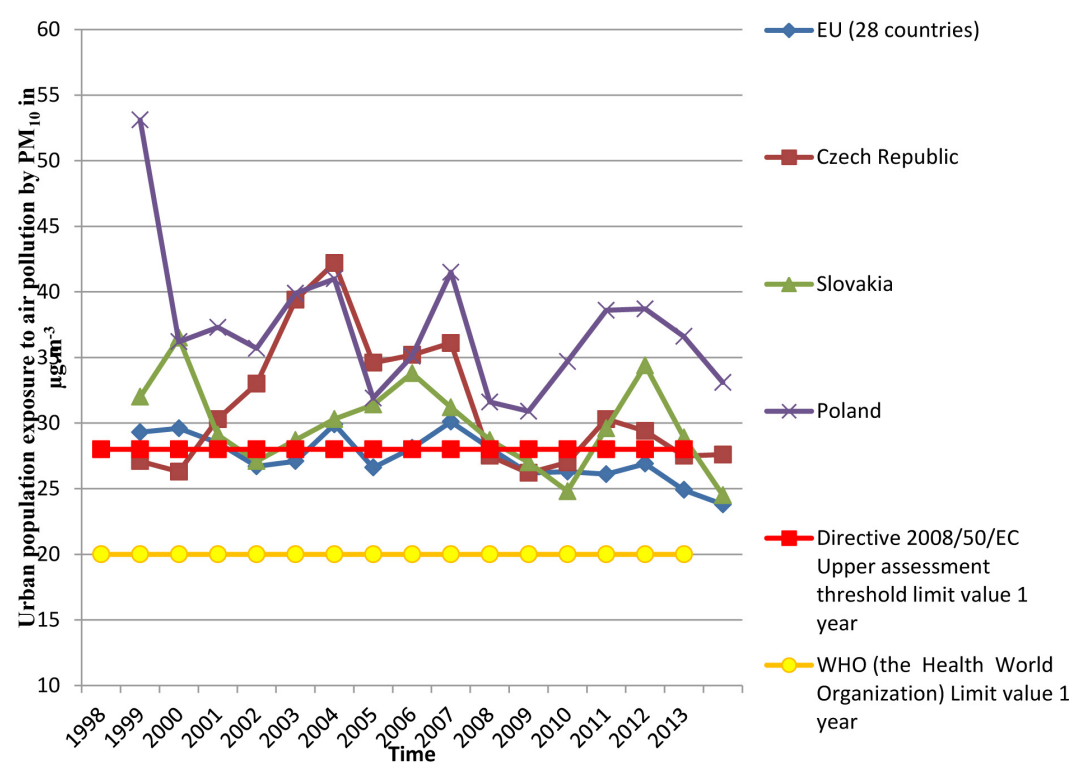

Fig. 2. Development of measured $\mathrm{PM}_{10}$ imission in selected countries in the years 1998-2013

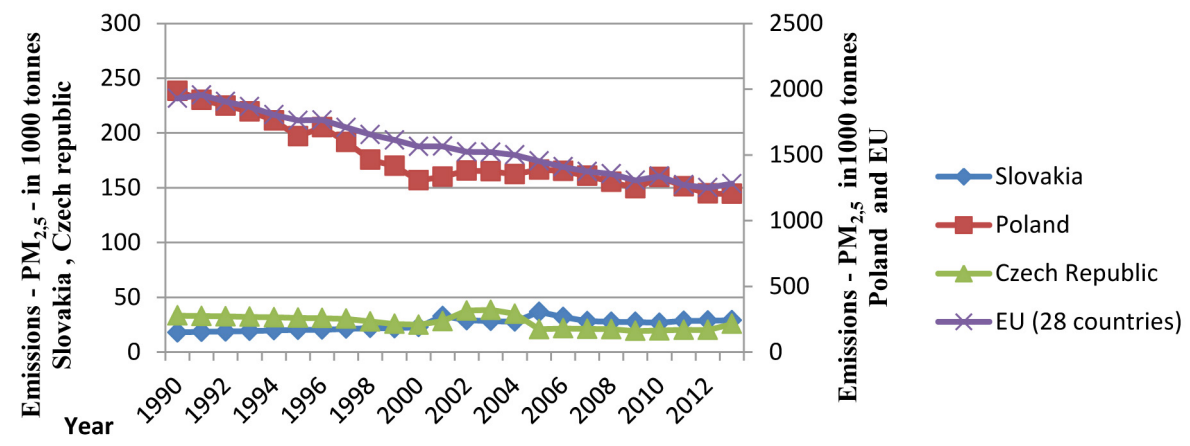

Fig. 3. Development of $\mathrm{PM}_{2,5}$ emission in chosen localities for the years 1990-2013 

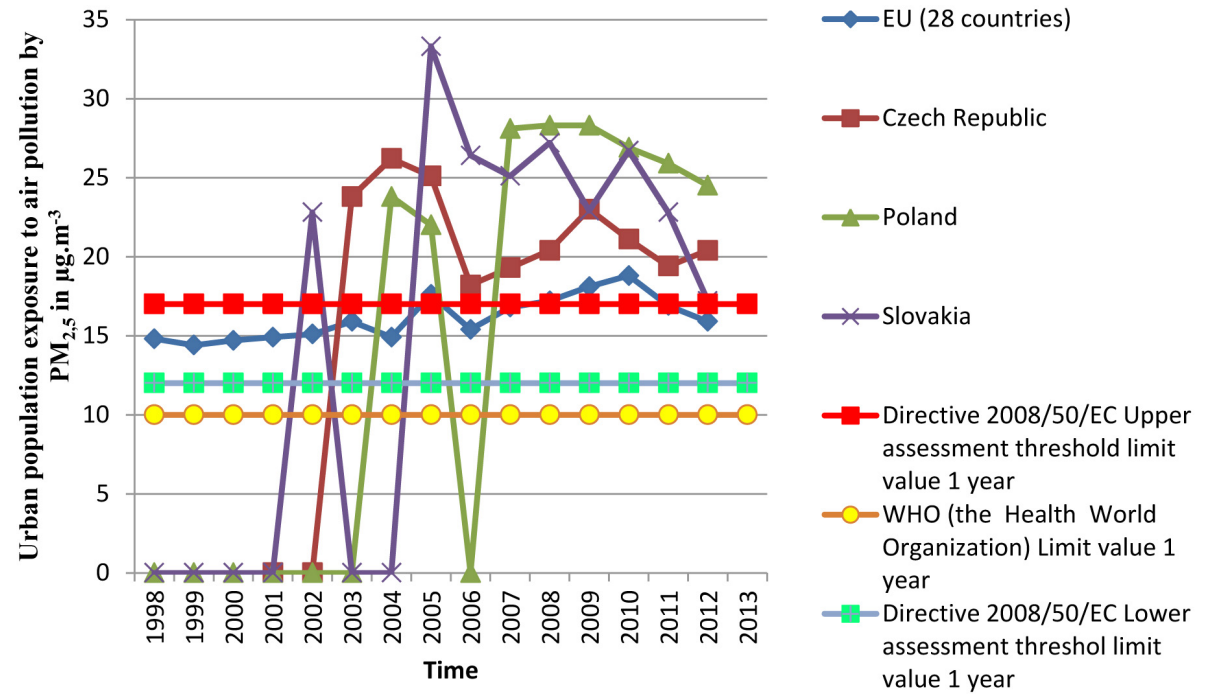

Fig. 4. Development of measured $\mathrm{PM}_{2,5}$ imissions in selected states in the years 1998-2013

The $\mathrm{NO}_{\mathrm{x}}$ emissions in $\mu \mathrm{g} . \mathrm{m}^{-3}$ (Fig.6), for the monitored period 1992-2013, are compared with the limit values determined by EU and WHO. All considered countries are within the limit values from the year 2003 .
The $\mathrm{NO}_{\mathrm{x}}$ emission for the countries in question (Fig.5) for the years 1990-2013 exhibited a decreasing trend and it causes the application of individual states measures for releasing polluted materials into the air.

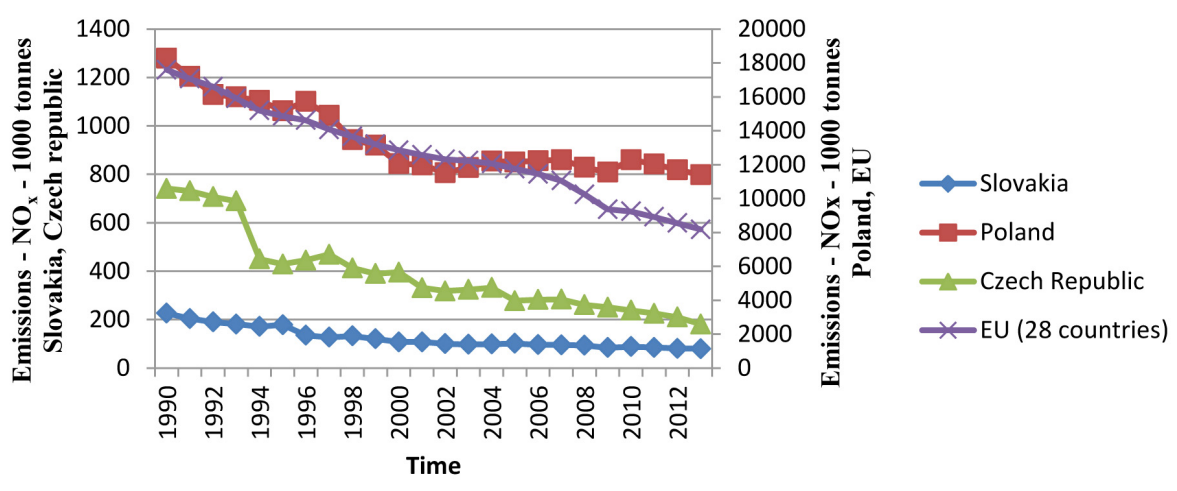

Fig. 5. Development of $\mathrm{NO}_{\mathrm{x}}$ emission in chosen localities for the years 1990-2013

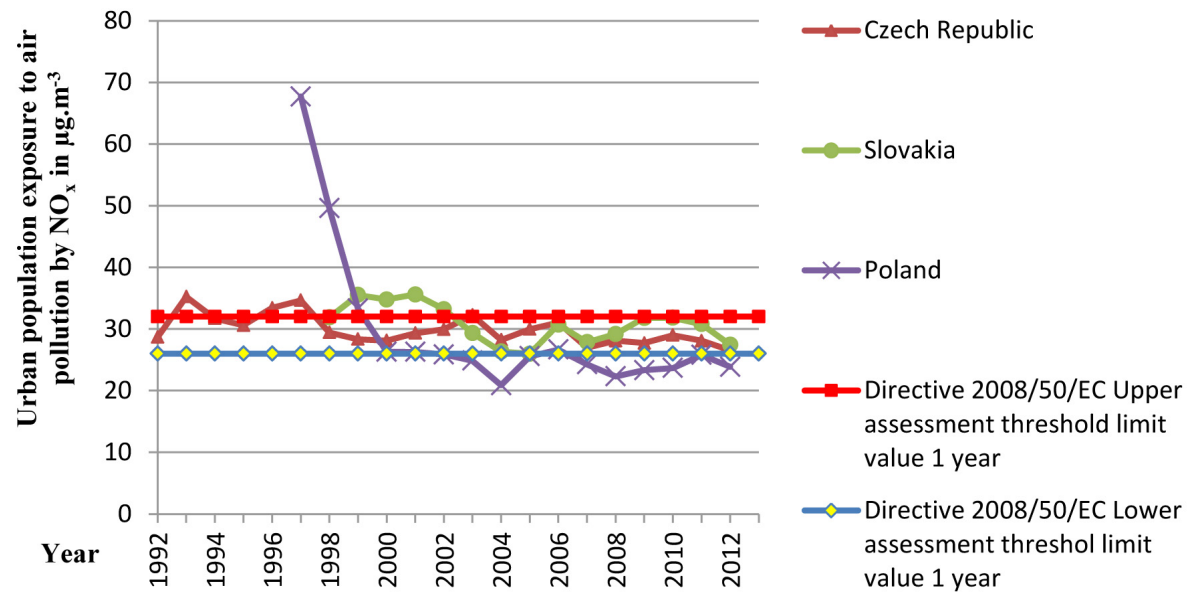

Fig. 6. Development of measured $\mathrm{NO}_{\mathrm{x}}$ imission in the chosen states in the years 1998-2013 


\section{CONCLUSIONS}

1. The only one way of exposure to PM by which could infiltrate into human body is inhalation. Health importance of the dust depends on the element size. So far, larger elements (over $10 \mu \mathrm{m})$ can cause only irritation of upper respiratory organs with coughing and sneezing and the elements under $2.5 \mu \mathrm{m}$ can permeate to lungs alveolus and they can accumulate in lungs or permeate to blood circulation. From this point of view, the dustiness index is divided into total dust (TSP), elements under 10 $\mu \mathrm{m}$ and particles under $2.5 \mu \mathrm{m}\left(\mathrm{PM}_{2,5}\right)$. Small domestic heaters produce more than one third of all fine dust emissions in the Czech Republic and Poland. Significant improvements to the current situation can only be achieved by taking the measures that will be based on an objective assessment pertaining to the impact of individual combustion technologies and the quality of the fuel used. Increased dustiness in the air generally affects the respiratory organs and occurs together with other pollutants, such as sulphur dioxide or nitrogen oxide.

2. The air quality is dependent on the air flow and airflow transmission. Therefore, the air quality changes for the countries concerned need to have a common framework and the country must jointly participate in the measures to improve the air quality. A significant change occurred in the years 2003 to 2004, when the countries joined the EU and adapted the national conditions of EU legislation.

3. The efforts to improve the situation must continue not only in industry but also in dealing with small domestic sources of heating. It will be important to regulate the particulate matter $\mathrm{PM}$ and in many EU countries, the regulation of their emissions will change significantly.

\section{Acknowledgements}

This study was supported by the grant APVV16-0278: Use of hydromelioration structures for mitigation of the negative extreme hydrological phenomena effects and their impacts on the quality of water bodies in agricultural landscapes by The Slovak Research and Development Agency

\section{REFERENCES}

1. Air quality in Europe - 2012 report, European Environment Agency, Luxembourg: Office for Official Publications of the European Union, (2012), 104 pp. ISBN 978-92-9213-328-3, ISSN 1725-9177 (C) EEA, Copenhagen, 2012

2. Air quality in Europe - 2013 report, European Environment Agency, Luxembourg: Office for Official Publications of the European Union, (2013), 107 pp. ISBN 978-92-9213-328-3, ISSN 1725-9177 (C) EEA, Copenhagen, 2013

3. Flash Eurobarometer 360, 2013. Attitudes Of Europeans Towards Air Quality, January 2013, http:// ec.europa.eu/public_opinion/flash/fl_360_sum_ en.pdf

4. Gozzil F., Della Ventura G., Marcelli A., Lucci F. 2017. Current Status of Particulate Matter Pollution in Europe and Future Perspectives: a Review JMES, 2017 Volume 8, Issue 6, Page 1901-1909, ISSN : 2028-2508

5. Hemerka J., 2010. Ochrana ovzduší, České vysoké učení technické v Praze. Strojní fakulta ISBN 800104646X, 9788001046463

6. Holland, M., Watkiss, P., Pye, S., Oliveira, A., Van Regemorter, D. 2005. Cost-benefit Analysis of Policy Option Scenarios for the Clean Air for Europe Programme (CAFE), European Commission, DG Environment, AEAT/ED48763001/CBA-CAFE, ABC scenarios, Brussels, Belgium.

7. Homer - Dixon, T. F.1999. On the Threshold: Environmental Changes as Causes of Acute Conflict. In: International Security. Vol. 16, No. 2. Trudeau Centre for Peace and Conflict Studies, University of Toronto. <http://www.library.utoronto.ca/pcs/ thresh/thresh1.htm>, 1999.

8. Leitmanová, M., Muchová, Z., Stred’anská, A., 2013. Concept of information system for land consolidation projects. In: Acta horticulturae et regiotecturae. Vol. 16, no. 2 (2013), s. 40-43. ISSN 1335-2563.

9. Lenárt, R. et al. 2012. The monitoring of SO2 immissions in power plant Nováky area. In: Krajinné inžinierstvo-trendy a perspektívy. 1 CDROM (220p.). 978-80-552-0961-6 Krajinné inžinierstvo - trendy a perspektívy. Nitra. Slovenská pol’nohospodárska univerzita, 2012.

10. Monteiroa.F, Sá M. at all 2017. How healthy will be the air quality in 2050? Air Quality Atmosphere \& Health February2017, DOI: 10.1007/ s11869-017-0466-z

11. Nowicki, M., 1993. Environment in Poland. Issues and Solutions. Kluwer Academic Publishers, Dordrecht/Boston/London, Dordrecht, The Netherlands 
12. Pokrývková J. Lackoová L. at all 2016. The Impact of Air Pollution on Rainwater Quality, Ochrona Srodowiska, January 2016, 18(1) p.303-321, ISSN 1506-218X

13. Ramanathan, V. Feng, Y. 2009. Air pollution, greenhouse gases and climate change: Global and regional perspectives. In: Atmospheric Environment, Vol. 43, 2009, p.37-50.
14. Werner M., Kryza M. Dore A.J. Wałaszek K., 2014. The Impact of Transboundary Transport of Air Pollutants on Air Quality in the United Kingdom and Poland, Air Pollution Modelling and its Application XXIII, DOI: 10.1007/978-3-319-04379-1_53

15. Zellner, R. 1999. Global Aspects of Atmospheric Chemistry. Springer, Germany. 334 p. ISBN 3-7985-1127-6. 